\title{
The Clinical and Financial Burden of Early Dialysis After Deceased Donor Kidney Transplantation
}

Paula M. Buchanan'1, Mark A. Schnitzler ${ }^{1}$, David Axelrod ${ }^{2}$, Paolo R. Salvalaggio ${ }^{3}$ and Krista L. Lentine ${ }^{1,4 *}$

${ }^{1}$ Center for Outcomes Research, Saint Louis University, St. Louis, MO, USA

${ }^{2}$ Department of Surgery, Dartmouth-Hitchcock Medical Center, Hanover, New Hampshire, USA

${ }^{3}$ Liver Transplant Unit, Hospital Israelita Albert Einstein, Sao Paulo, Brazil

${ }^{4}$ Division of Nephrology, Saint Louis University School of Medicine, St. Louis, MO, USA

\begin{abstract}
Background: The economic implications of dialysis-requiring allograft dysfunction early after kidney transplantation are not well-described.

Methods: Data for Medicare-insured adult kidney transplant recipients in 1995-2004 who did not develop permanent graft failure in the first 90 days were drawn from the United States Renal Data System. We identified dialysis treatment records from Medicare claims and categorized patients according to frequency and duration of post-transplant dialysis as: first week (delayed graft function, DGF), second week, weeks 3 or 4 , second month, or third month.Associations of dialysis requirements with Medicare payments for the transplant hospitalization and over the next three years were estimated with multivariable linear regression. Graft and patient survival according to early dialysis requirements were examined with multivariable survival analysis.
\end{abstract}

Results: Among 37,533 recipients, 15,314 (41\%) experienced DGF and 3,184 (21\% of those with DGF) received dialysis beyond the first week. Compared with no dialysis in the first 3 months, adjusted marginal first-year costs associated with early post-transplant dialysis ranged from $\$ 6,467$ for dialysis requirement limited to first week to $\$ 27,606$ for dialysis in multiple periods $(p<0.0001)$. Patients who experienced DGF and received dialysis in $>2$ early periods were more than twice as likely to lose their grafts within 3 years as those without early dialysis requirements.

Conclusions: While dialysis in the first week post-transplant is an adverse risk marker, early dialysis in weeks 2 to 12 is associated with similarly adverse, if not worse, costs and clinical consequences. This observation supports a need for broader definition of DGF.

Keywords: Delayed graft function; Economic analysis; Kidney transplantation; Medicare; Allograftsurvival; Outcomes

\section{Introduction}

Renal transplantation provides the best clinical outcomes, quality of life and cost-savings among the options for renal replacement therapy [1-3]. From 1997 through 2010 the number of patients on the wait-list for a renal transplant increased more than two-fold, to $>80,000$ patients [4]. The number of patients awaiting transplant in 2010 was almost five-times the number transplants performed [4]. To improve access to transplant in the context of this organ shortage, many centers have liberalized criteria for organ acceptance. From 1993 to 2008, the relative frequency of expanded criteria donor (ECD) allograft use rose from $7.4 \%$ to $22 \%$ among U.S. Transplantation of kidneys donated after cardiac death (DCD) also increased from $<1 \%$ to $12.4 \%$ in this period [5].

The increased utilization of ECD and DCD kidneys has resulted in a higher rate of delayed graft function (DGF) [5-7]. In general, DGF is defined as receiving dialysis in the first week post-transplant. However, other investigators have attempt to further categorize the clinical implications of DGF according to the severity and persistence graft dysfunction [8-10]. Typically, DGF results in increased costs in transplant recipients compared to those who do not experience DGF, in part due to a longer length of stay for the transplant hospitalization and need for hemodialysis $[11,12]$. DGF also increases the risk of rejection, graft failure and death, which can add substantial costs [6,13-15].

Current data on the cost implications of DGF are largely drawn from single center studies focused on the transplant hospitalization, and consider DGF as a binary event $[2,6,11,12,16]$. To improve understanding of the financial and clinical outcome implications of early post-transplant dialysis requirements after kidney transplantation, we performed a historical cohort study of large sample of Medicare beneficiaries registered in the United States Renal Data System (USRDS). Medicare claims records were used to identify the frequency and duration of dialysis requirements in the first 90 days after transplant. We also quantified associations of early graft function, as defined by the timing and persistence of dialysis requirements, with subsequent Medicare costs, permanent graft failure, and patient death over time.

\section{Methods}

\section{Study data and sampling criteria}

Study data were drawn from the USRDS [17]. The USRDS is a database that links the Organ Procurement and Transplantation

*Corresponding author: Krista L. Lentine, Saint Louis University Center for Outcomes Research, 3545 Lafayette Avenue, Salus Center, 4th Floor, SLUCOR, St. Louis, MO 63104, USA, Tel: 314-977-3000; Fax: 314- 977-1101; E-mail: lentinek@ slu.edu

Received October 04, 2011; Accepted October 28, 2011; Published November 02, 2011

Citation: Buchanan PM, Schnitzler MA, Axelrod D, Salvalaggio PR, Lentine KL (2011) The Clinical and Financial Burden of Early Dialysis After Deceased Donor Kidney Transplantation. J Nephrol Therapeutic S4:001. doi:10.4172/2161-0959. S4-001

Copyright: (c) 2011 Buchanan PM, et al. This is an open-access article distributed under the terms of the Creative Commons Attribution License, which permits unrestricted use, distribution, and reproduction in any medium, provided the original author and source are credited. 
network (OPTN) renal transplant registry data with administrative data from the Health Care Financing Administration (HCFA). The OPTN registry contains descriptive and clinical data on all kidney transplants performed in the United States. HCFA administrative data capture billing claims for Medicare-insured renal transplant recipients.

The study sample includes all adult (age $>18$ year old) deceaseddonor renal transplant recipients in the USRDS registry from 1995 to 2004 with Medicare as their primary payer. Medicare primary payer status at transplant was defined by USRDS "Payer History" records and a total Medicare payment for the initial transplant hospitalization exceeding $\$ 15,000$, as per previous reports [18]. Patients with multipleorgan transplants or previous transplants were excluded. Patients who experienced permanent graft failure, as reported to the OPTN registry, within the first 90 days post-transplant were also excluded. In addition, patients with Medicare claims for dialysis within 2 weeks after the initial 90 day assessment period (days 91-104 post-transplant) were also removed from the sample to ensure that patients with permanent early graft failure who return to chronic dialysis were not included in this study of delayed function.

\section{Dialysis records and categorization of early dialysis requirements}

Early post-transplant dialysis requirements were categorized using Medicare claims for dialysis within 90 days-post transplant as well as center reports of DGF to the OPTN registry. Medicare claims for dialysis were identified by a service code for dialysis, a place of service code for ESRD treatment, or indicated dialysis treatment modality on a billing claim. Dialysis claims were categorized according to occurrence in the following post-transplant periods: the first week, the second week, weeks 3 or 4 , the second month, or the third month post-transplant. We defined DGF as an indication of DGF in the OPTN registry and/ or any claims for dialysis in the first week post-transplant. Patients were then categorized into mutually exclusive groups based on DGF and subsequent dialysis claims as follows: 1) DGF with dialysis claims in the first week post-transplant only, 2) DGF and dialysis claims in one additional post-transplant period, 3) DGF and dialysis claims in $>1$ additional post-transplant periods, 4) no DGF but some claims for dialysis in days 8 to 90 post-transplant, and 5) no DGF and no dialysis claims within 90 days post-transplant.

\section{Outcomes}

The primary outcome was post-transplant costs, as defined by all post-transplant Medicare payments for a recipient within specified intervals. The cost measure includes Medicare payments to the recipients' dialysis center, health providers, and treatment centers including hospitals. Payments were adjusted for inflation with the medical component of the consumer price index using the year 2004 as the base year [19]. Claims from the date of transplant until three years post transplant (the time when Medicare coverage after transplant ends in the absence of age $>65$ or disability), death, or end of study date (December 31, 2004) were captured. The transplant hospitalization costs comprised all claims with a diagnosis-related group (DRG) code of 302, which indicates hospitalization for a kidney transplant. One, two, and three year post transplant costs were computed as the sum of the patient's claims from transplant hospitalization to the indicated follow-up time. Patients who had incomplete follow-up due to loss of Medicare or end of study within an interval of analysis were excluded from that and subsequent intervals. Patients who died within an interval were included in all intervals with payments after date of death set to zero dollars.
Secondary outcomes included: reported creatinine and estimated glomerular filtration rate (eGFR) at discharge and at 6 and 12 months post-transplant, length of transplant hospitalization stay, rejection (within 3 years post transplant), death-censored graft failure, and mortality, as defined by OPTN reports. eGFR was calculated by the 4-variable MDRD equation, that has been demonstrated to perform well in transplant recipients [20]. Patients with missing creatinine values were excluded from the analysis of renal function for the periods in which they had missing data. Rejection was defined as any OPTN reported occurrence of acute or chronic rejection, rejection as a cause of graft failure, or administration of anti-rejection immunosuppression within one, two, or three years post-transplant. At time of discharge, data on length of stay and renal function were available for 22,269 $(60 \%)$ and 36,867 (98\%) of the patients in the study, respectively. At six months and one-year post-transplant there were 35,514 (95\% of total) and 33,957 (90.5\% of total) patients with renal function data available, respectively.

Covariate data were ascertained from OPTN records including: patient gender, race, ethnicity, age at transplant, body mass index (BMI), primary cause of ESRD, pre-transplant dialysis duration, and peak panel reactive antibody (PRA) percent; donor type (standard criteria donor [SCD], ECD, DCD), gender, race, ethnicity, age, BMI, cause of death, terminal creatinine $\geq 1.5 \mathrm{mg} / \mathrm{dL}$, history of hypertension, diabetes; donor-recipient cytomegalovirus (CMV) sero-pairing, types and number of ABDR HLA mismatches, cold ischemia time, and year of transplant.

\section{Statistical analysis}

Distributions of recipient, donor, and transplant characteristic were compared between the groups defined by dialysis utilization using chi-square and t-tests. Missing baseline data was categorized as missing, other or unknown depending on the type of characteristic.

The unadjusted mean cost of transplant hospitalization, and costs incurred in one, two, and three years post-transplant were compared for all groups using the non-parametric Wilcoxon rank-sum test Multivariate linear regression analysis was performed to compare costs within the four periods according to dialysis utilization, adjusting for recipient, donor, and transplant characteristics. Secondary outcomes were analyzed using chi-squared and ANOVA tests. Patient and graft survival after transplant were estimated by the Kaplan-Meier method. We used Cox Proportional Hazard analyses to examine the impact of early post-transplant dialysis on graft and patient survival, adjusting for the baseline covariates. An alpha level of 0.05 was used for all significance tests. Analyses were performed using SAS v.9.1 (SAS Institute, Cary, NC).

\section{Results}

We identified 37,533 Medicare insured adult renal recipients who met selection criteria. Of these recipients, 15,314 (41\%) experienced DGF and 3,184 (21\% of those with DGF) received dialysis beyond the first week post-transplant. Patients required varying intensity of posttransplant dialysis treatment: 12,130 (32.2\%) patients had DGF but no dialysis beyond the first week post-transplant, 2,144 (5.7\%) had DGF and dialysis in 1 additional period (week 1 and either week 2, weeks 3 or 4 , the second month, or the third month), 1,040 (2.8\%) had DGF and early dialysis in $>1$ additional period, 1,525 (4.1\%) without DGF and but had some early dialysis in days 8 to 90 , and 20,694 (55.1\%) did not experience DGF or require dialysis in the 90 days after transplant.

The demographic characteristics of the transplant recipients varied 
Citation: Buchanan PM, Schnitzler MA, Axelrod D, Salvalaggio PR, Lentine KL (2011) The Clinical and Financial Burden of Early Dialysis After Deceased Donor Kidney Transplantation. J Nephrol Therapeutic S4:001. doi:10.4172/2161-0959.S4-001

Page 3 of 12

significantly as a function of the need for and duration of dialysis treatment (Table 1). African Americans experienced more DGF than white recipients and were more likely to require some dialysis after the first week. Obese recipients were the most likely to experience DGF, but the percentage of obese patients requiring dialysis after the first two weeks was similar to non-obese recipients. Recipients of SCD allografts were less likely to experience DGF than patients transplanted with ECD or DCD organs (38.3\% compared to 52.1 and $62.8 \%$, respectively, $\mathrm{p}<0.0001)$. The percentage of transplants complicated by DGF increased substantially over the years of study, from $26 \%$ in 1995 to $54 \%$ in $2004(\mathrm{p}<0.0001)$.

\begin{tabular}{|c|c|c|c|c|c|c|}
\hline & $\begin{array}{l}\text { DGF with early } \\
\text { week only, }{ }^{\ddagger} \text { (\%) }\end{array}$ & $\begin{array}{l}\text { DGF and early } \\
\text { dialysis in } 1 \\
\text { additional period, } \\
\begin{array}{l}\neq \\
\text { n(\%)) }\end{array}\end{array}$ & $\begin{array}{l}\text { DGF and early } \\
\text { dialysis in >1 } \\
\text { additional period, } \\
\quad \neq n(\%)\end{array}$ & $\begin{array}{l}\text { No DGF but some } \\
\text { early dialysis, } \\
\neq n(\%)^{*}\end{array}$ & $\begin{array}{l}\text { No DGF and no } \\
\text { dialysis, } \neq n(\%)^{*}\end{array}$ & $\mathrm{p}$-value ${ }^{\dagger}$ \\
\hline \multicolumn{7}{|l|}{ Recipient Characteristics } \\
\hline Female & $4349(29.8)$ & $780(5.4)$ & $346(2.4)$ & $572(3.9)$ & $8546(58.6)$ & $<0.0001$ \\
\hline Race & & & & & & $<0.0001$ \\
\hline $\begin{array}{l}\text { African } \\
\text { American }\end{array}$ & $4193(34.6)$ & $851(7.0)$ & $440(3.6)$ & $542(4.5)$ & $6099(50.3)$ & \\
\hline White & $7129(31.0)$ & $1165(5.1)$ & $543(2.4)$ & $889(3.9)$ & $13247(57.7)$ & \\
\hline Other & $808(33.2)$ & $128(5.3)$ & $57(2.3)$ & $93(3.8)$ & $1348(55.8)$ & \\
\hline Hispanic & $1336(31.3)$ & $263(6.2)$ & $135(3.2)$ & $156(3.7)$ & $2383(55.8)$ & 0.08 \\
\hline Age (years) & & & & & & $<0.0001$ \\
\hline $18-30$ & $900(27.5)$ & $155(4.7)$ & $74(2.3)$ & $135(4.1)$ & $2015(61.5)$ & \\
\hline $31-44$ & $3038(30.1)$ & $528(5.2)$ & $263(2.6)$ & $441(4.4)$ & $5852(57.8)$ & \\
\hline $45-59$ & $4796(33.1)$ & $875(6.0)$ & $417(2.9)$ & $594(4.1)$ & $7828(54.0)$ & \\
\hline$\geq 60$ & $3396(35.3)$ & $586(6.1)$ & $286(3.0)$ & $355(3.7)$ & $4999(52.0)$ & \\
\hline BMI category $\left(\mathrm{kg} / \mathrm{m}^{2}\right)$ & & & & & & $<0.0001$ \\
\hline $\mathrm{BMI}<10$ or Missing & $2673(28.6)$ & $541(5.8)$ & $280(3.0)$ & $420(4.5)$ & $5423(58.1)$ & \\
\hline $\mathrm{BMI} \geq 10$ to $<25$ & $3503(29.0)$ & $582(4.8)$ & $289(2.4)$ & $499(4.1)$ & $7206(59.7)$ & \\
\hline $\mathrm{BMI} \geq 25$ to $<30$ & 3249 (34.8) & $544(5.8)$ & $259(2.8)$ & $355(3.8)$ & $4929(52.8)$ & \\
\hline $\mathrm{BMI} \geq 30$ & 2705 (39.9) & $477(7.0)$ & $212(3.1)$ & $251(3.7)$ & $3136(46.3)$ & \\
\hline Primary cause of ESRD & & & & & & $<0.0001$ \\
\hline $\begin{array}{l}\text { Diabetes } \\
\text { mellitus }\end{array}$ & $3048(31.8)$ & $561(5.8)$ & $234(2.4)$ & $369(3.8)$ & $5389(56.1)$ & \\
\hline Glomerulonephritis & $2155(30.8)$ & $351(5.0)$ & $163(2.3)$ & $277(4.0)$ & $4049(57.9)$ & \\
\hline Polycystic kidney disease & $850(31.7)$ & $133(5.0)$ & $58(2.2)$ & $113(4.2)$ & $1530(57.0)$ & \\
\hline Hypertension & 3001 (32.9) & $567(6.2)$ & 327 (3.6) & $410(4.5)$ & $4821(52.8)$ & \\
\hline Other & 1594 (34.3) & 241 (5.2) & $109(3.3)$ & $167(3.6)$ & $2539(54.6)$ & \\
\hline Unknown & $1482(33.1)$ & 291 (6.5) & $149(2.3)$ & $189(4.2)$ & 2366 (52.9) & \\
\hline Pre-Transplant Dialysis Duration & & & & & & $<0.0001$ \\
\hline None (pre-emptive) & $941(35.9)$ & $159(6.1)$ & $59(2.3)$ & $105(4.0)$ & $1356(51.8)$ & \\
\hline $0-12$ months & $784(25.9)$ & $94(3.1)$ & $48(1.6)$ & $118(3.9)$ & $1985(65.5)$ & \\
\hline 13-24 months & $1594(28.0)$ & $233(4.1)$ & $104(1.8)$ & $232(4.1)$ & $3533(62.0)$ & \\
\hline $25-60$ months & $5905(32.4)$ & $1074(5.9)$ & $513(2.8)$ & $750(4.1)$ & $9972(54.8)$ & \\
\hline$>60$ months & $2906(36.4)$ & $584(7.3)$ & $316(4.0)$ & $320(4.0)$ & $3848(48.3)$ & \\
\hline \multicolumn{7}{|l|}{ Donor Characteristics } \\
\hline Female & $5157(34.0)$ & $842(5.5)$ & $422(2.8)$ & $630(4.2)$ & $8137(53.6)$ & $<0.0001$ \\
\hline Hispanic & $1336(31.3)$ & $263(6.2)$ & $135(3.2)$ & $156(3.7)$ & $2383(55.8)$ & 0.08 \\
\hline Race & & & & & & $<0.0001$ \\
\hline African American & $1394(31.0)$ & $274(6.1)$ & $138(3.1)$ & $224(5.0)$ & $2461(54.8)$ & \\
\hline White & $10223(32.3)$ & $1786(5.7)$ & $860(2.7)$ & $1232(3.9)$ & $17515(55.4)$ & \\
\hline Other & $513(36.0)$ & $84(5.9)$ & $42(3.0)$ & $69(4.8)$ & 718 (50.4) & \\
\hline Age (years) & & & & & & $<0.0001$ \\
\hline
\end{tabular}


Citation: Buchanan PM, Schnitzler MA, Axelrod D, Salvalaggio PR, Lentine KL (2011) The Clinical and Financial Burden of Early Dialysis After Deceased Donor Kidney Transplantation. J Nephrol Therapeutic S4:001. doi:10.4172/2161-0959.S4-001

Page 4 of 12

\begin{tabular}{|c|c|c|c|c|c|c|}
\hline$<18$ & $1423(25.3)$ & $207(3.7)$ & $95(1.7)$ & $251(4.5)$ & $3658(64.9)$ & \\
\hline $18-30$ & $2002(26.5)$ & $321(4.3)$ & $120(1.6)$ & $322(4.3)$ & $4790(63.4)$ & \\
\hline $31-44$ & $2392(31.4)$ & $431(5.7)$ & $206(2.7)$ & $313(4.1)$ & $4274(56.1)$ & \\
\hline $45-59$ & $3403(37.0)$ & $657(7.1)$ & 339 (3.7) & $363(3.9)$ & $4444(48.3)$ & \\
\hline$\geq 60$ & $1337(39.1)$ & $265(7.8)$ & $159(4.7)$ & $141(4.1)$ & $1518(44.4)$ & \\
\hline BMI category $\left(\mathbf{k g} / \mathbf{m}^{2}\right)$ & & & & & & $<0.0001$ \\
\hline BMI $<10$ or Missing & $326(22.2)$ & $68(4.6)$ & $49(3.3)$ & $86(5.9)$ & $938(63.9)$ & \\
\hline $\mathrm{BMI} \geq 10$ to $<25$ & $5701(29.5)$ & $916(4.7)$ & $458(2.4)$ & $803(4.2)$ & $11480(59.3)$ & \\
\hline $\mathrm{BMI} \geq 25$ to $<30$ & $3574(34.4)$ & $695(6.7)$ & $313(3.0)$ & $400(3.9)$ & $5405(52.0)$ & \\
\hline $\mathrm{BMI} \geq 30$ & $2529(40.0)$ & $465(7.4)$ & $220(3.5)$ & $236(3.7)$ & $2872(45.4)$ & \\
\hline Death due to stroke & $5452(37.0)$ & $982(6.7)$ & $535(3.6)$ & $595(4.0)$ & $7169(48.7)$ & $<0.0001$ \\
\hline Terminal Creatinine $\geq 1.5$ & $2083(38.5)$ & $430(7.9)$ & $234(4.3)$ & $233(4.3)$ & $2433(45.0)$ & $<0.0001$ \\
\hline Hypertension history & $2929(40.1)$ & $555(7.6)$ & $332(4.5)$ & $587(3.9)$ & $3203(43.8)$ & $<0.0001$ \\
\hline Diabetes & $563(39.3)$ & $92(6.4)$ & $71(5.0)$ & $41(2.9)$ & $664(46.4)$ & $<0.0001$ \\
\hline CMV sero-positive & $7539(32.7)$ & $1348(5.9)$ & $683(3.0)$ & $930(4.0)$ & $12562(54.5)$ & 0.002 \\
\hline \multicolumn{7}{|l|}{ Transplant Factors } \\
\hline \multicolumn{7}{|l|}{ Donor type } \\
\hline ECD & $2037(39.4)$ & $402(7.8)$ & $253(4.9)$ & $203(3.9)$ & $2270(44.0)$ & $<0.0001$ \\
\hline DCD & $409(44.3)$ & $121(13.1)$ & $50(5.4)$ & $23(2.5)$ & $320(34.7)$ & $<0.0001$ \\
\hline SCD & $9684(30.8)$ & $1621(5.2)$ & $737(2.3)$ & $1299(4.1)$ & $18104(57.6)$ & $<0.0001$ \\
\hline Peak Panel Reactive Antibody ( \%) & & & & & & $<0.0001$ \\
\hline $0-10$ & $8342(31.6)$ & $1435(5.4)$ & $728(2.8)$ & $1088(4.1)$ & $14814(56.1)$ & \\
\hline $11-30$ & $1236(31.3)$ & $220(5.6)$ & $106(2.7)$ & $175(4.4)$ & $2218(56.1)$ & \\
\hline$>30$ & $1688(32.7)$ & $355(6.9)$ & $163(3.2)$ & $198(3.8)$ & $2756(53.4)$ & \\
\hline Unknown & $864(43.0)$ & $134(6.7)$ & $43(2.1)$ & $64(3.2)$ & $903(45.1)$ & \\
\hline HLA Mismatches & & & & & & $<0.0001$ \\
\hline 0 & $1072(32.8)$ & $145(5.6)$ & $60(1.8)$ & $104(3.2)$ & $1888(57.8)$ & \\
\hline 1 & $673(28.6)$ & $119(4.4)$ & $57(2.4)$ & $78(3.3)$ & $1424(60.6)$ & \\
\hline 2 & $1237(30.5)$ & $219(5.1)$ & $91(2.2)$ & $192(4.7)$ & $2318(57.1)$ & \\
\hline 3 & $2528(31.2)$ & $449(5.5)$ & $231(2.9)$ & $354(4.4)$ & $4547(56.1)$ & \\
\hline 4 & 3108 (33.3) & $564(6.0)$ & $254(2.7)$ & $384(4.1)$ & $5036(53.9)$ & \\
\hline 5 & $2324(33.6)$ & $433(6.3)$ & $231(3.3)$ & $270(3.9)$ & $3653(52.9)$ & \\
\hline 6 & $930(34.9)$ & $169(6.4)$ & $92(3.5)$ & $99(3.7)$ & $1373(51.6)$ & \\
\hline Unknown & $258(31.2)$ & $46(5.6)$ & $24(2.9)$ & $44(5.3)$ & $455(55.0)$ & \\
\hline CMV sero-pairing & & & & & & $<0.0001$ \\
\hline Donor - / Recipient - & $1289(30.7)$ & $209(5.0)$ & $97(2.7)$ & $173(4.1)$ & $2663(57.5)$ & \\
\hline Donor - / Recipient + & $2824(33.1)$ & $502(5.9)$ & $229(2.7)$ & $355(4.2)$ & $4627(54.2)$ & \\
\hline Donor + / Recipient - & 1930 (32.9) & $313(6.2)$ & $168(3.1)$ & $256(3.9)$ & $3611(53.8)$ & \\
\hline Donor + / Recipient + & $4895(29.1)$ & $918(4.7)$ & $466(2.2)$ & $586(3.9)$ & $7998(60.1)$ & \\
\hline Unknown & $1192(34.8)$ & $202(5.9)$ & $80(2.3)$ & $155(4.5)$ & $1795(52.4)$ & \\
\hline Year & & & & & & $<0.0001$ \\
\hline 1995 & $767(20.1)$ & $148(3.9)$ & $88(2.3)$ & $253(6.6)$ & $2562(67.1)$ & \\
\hline 1996 & $760(20.5)$ & $187(5.0)$ & $111(3.0)$ & $224(6.0)$ & $2433(65.5)$ & \\
\hline 1997 & $835(21.4)$ & $183(4.7)$ & $92(2.4)$ & $195(5.0)$ & $2595(66.5)$ & \\
\hline 1998 & $830(22.0)$ & $207(5.5)$ & $106(2.8)$ & $179(4.8)$ & $2449(64.9)$ & \\
\hline 1999 & $1132(31.3)$ & $220(6.1)$ & $90(2.5)$ & $158(4.4)$ & $2012(55.7)$ & \\
\hline 2000 & $1405(38.2)$ & $224(6.1)$ & $97(2.6)$ & $118(3.2)$ & $1837(49.9)$ & \\
\hline 2001 & $1544(39.5)$ & $239(6.1)$ & $126(3.2)$ & $108(2.8)$ & $1888(48.4)$ & \\
\hline
\end{tabular}


Citation: Buchanan PM, Schnitzler MA, Axelrod D, Salvalaggio PR, Lentine KL (2011) The Clinical and Financial Burden of Early Dialysis After Deceased Donor Kidney Transplantation. J Nephrol Therapeutic S4:001. doi:10.4172/2161-0959.S4-001

Page 5 of 12

\begin{tabular}{|l|c|c|c|c|c|}
\hline 2002 & $1576(40.7)$ & $258(6.7)$ & $127(3.3)$ & $98(2.5)$ & $1812(46.8)$ \\
\hline 2003 & $1845(46.4)$ & $227(5.7)$ & $122(3.1)$ & $82(2.1)$ & $1698(42.7)$ \\
\hline 2004 & $1436(43.7)$ & $251(7.6)$ & $81(2.5)$ & $110(3.4)$ \\
\hline & Mean(std) & Mean(std) & Mean(std) & Mean(std) & Mean(std) \\
\hline Cold-time( hours) & $20.5(8.6)$ & $22.3(8.6)$ & $23.1(9.8)$ & $19.5(8.5)$ & $18.6(8.1)$ \\
\hline
\end{tabular}

${ }^{\dagger} \mathrm{P}$ values differences in trait distributions according to dialysis utilization were computed by the Chi-square test for categorical variables and the t-test for continuous variables.

* Percents given are row percents.

¥Periods of early dialysis were defined as first week, the second week, weeks 3 or 4 , the second month and the third month post-transplant

Table 1: Characteristics of Medicare-insured renal transplant recipients in 1995-2004 according to early post-transplant dialysis utilization ( $\mathrm{N}=37,533)$.

\begin{tabular}{|c|c|c|c|c|}
\hline Period & Dialysis Use & $\mathbf{N}$ & Mean (std) & p-value* \\
\hline \multirow{5}{*}{ Transplant hospitalization } & DGF with early dialysis first week only ${ }^{\dagger}$ & 12,130 & $\$ 31,451(23,144)$ & $<0.0001$ \\
\hline & DGF with early dialysis in 1 additional period $^{\dagger}$ & 2,144 & $\$ 31,242(17,649)$ & \\
\hline & DGF with early dialysis in $>1$ additional period $^{\dagger}$ & 1,040 & $\$ 33,280(20,487)$ & \\
\hline & No DGF but some dialysis ${ }^{\dagger}$ & 1,525 & $\$ 33,035(19,746)$ & \\
\hline & No DGF and no early dialysis ${ }^{\dagger}$ & 20,694 & $\$ 30,068(13,714)$ & \\
\hline \multirow{5}{*}{ One year post transplant } & DGF with early dialysis first week only ${ }^{\dagger}$ & 10,721 & $\$ 74,081(51,171)$ & $<0.0001$ \\
\hline & DGF with early dialysis in 1 additional period ${ }^{\dagger}$ & 1,904 & $\$ 87,330(71,645)$ & \\
\hline & DGF with early dialysis in $>1$ additional period $^{\dagger}$ & 963 & $\$ 98,651(64,521)$ & \\
\hline & No DGF but some dialysis ${ }^{\dagger}$ & 1,419 & $\$ 90,590(67,299)$ & \\
\hline & No DGF and no early dialysis ${ }^{\dagger}$ & 19,304 & $\$ 68,089(41,809)$ & \\
\hline \multirow{5}{*}{ Two years post transplant } & DGF with early dialysis first week only ${ }^{\dagger}$ & 8,964 & $\$ 98,621(69,100)$ & $<0.0001$ \\
\hline & DGF with early dialysis in 1 additional period ${ }^{\dagger}$ & 1,699 & $\$ 112,002(85,184)$ & \\
\hline & DGF with early dialysis in $>1$ additional period ${ }^{\dagger}$ & 859 & $\$ 129,105(83,008)$ & \\
\hline & No DGF but some dialysis ${ }^{\dagger}$ & 1,340 & $\$ 114,589(86,538)$ & \\
\hline & No DGF and no early dialysis ${ }^{\dagger}$ & 17,571 & $\$ 90,072(59,685)$ & \\
\hline \multirow{5}{*}{$\begin{array}{l}\text { Three years post } \\
\text { transplant }\end{array}$} & DGF with early dialysis first week only ${ }^{\dagger}$ & 7,273 & $\$ 121,063(84,526)$ & $<0.0001$ \\
\hline & DGF with early dialysis in 1 additional period ${ }^{\dagger}$ & 1,408 & $\$ 136,189(102,254)$ & \\
\hline & DGF with early dialysis in $>1$ additional period ${ }^{\dagger}$ & 710 & $\$ 156,079(102,681)$ & \\
\hline & No DGF but some dialysis ${ }^{\dagger}$ & 1,235 & $\$ 138,264(101,836)$ & \\
\hline & No DGF and no early dialysis ${ }^{\dagger}$ & 15,776 & $\$ 110,109(74,650)$ & \\
\hline
\end{tabular}

Costs adjusted to 2004 as the base year

${ }^{*} \mathrm{P}$ value for the difference in cost distribution according to early post-transplant dialysis utilization was computed by the Wilcoxon rank-sum test for continuous variables. ${ }^{\dagger}$ Periods of early dialysis were first week, the second week, weeks 3 or 4 , the second month and the third month post-transplant

Table 2: Average accumulated costs for transplant hospitalization and care over 1, 2, and 3 years post transplant among Medicare-insured renal recipients from 19952004 according to early post transplant dialysis utilization (in US dollars).

The average cost for patients who did not receive any dialysis in the 90 days post-transplant was less than all of the other groups across all time periods of interest (Table 2). Patients who did not experience DGF but required dialysis between 8 and 9 days were at least as expensive as those who were dialyzed within the first week post transplant. For all time periods the average total cost of medical care in patients who were dialyzed between days 8-90 was higher than that of recipients with DGF and dialysis in two or fewer periods. Compared to patients free of DGF and any early dialysis, those with dialysis in the first week incurred $\$ 1,400$ in additional costs during the transplant hospitalization and $\$ 6,000$ more by the end of the first year. Patients who had DGF who received dialysis in more than two periods had approximately $\$ 3,200$ more in costs for the transplant hospitalization than those without any dialysis utilization.

After multivariate regression analysis, patients who received some dialysis in the 90 days post-transplant are more expensive to care for than those without any early dialysis utilization at each time period (Table 3). Receiving dialysis within the first week after transplant was independently associated with $\$ 2,727$ in incremental costs compared to patients without DGF. The independent cost differential between these two groups increased over follow-up to $\$ 8,742$ at three years posttransplant; The need for sustained early dialysis or dialysis which began between 8 to 90 days, was also independently associated with notably increased total costs where compared to no dialysis utilization. After accounting for dialysis utilization, ECD and DCD transplant were still associated with more expenses than SCD grafts in the transplant hospitalization and first year post-transplant, although the difference in cost was only significant only for DCD transplants. After accounting for inflation, dialysis utilization, and recipient and donor factors, Medicare payments for post-transplant care declined over time. By 2004 Medicare reimbursed approximately $\$ 15,700$ less for the average transplant hospitalization than in 1995.

Both DGF and subsequent dialysis were found to dramatically impact patient survival (Table 4). By one year post-transplant the prevalence of any rejection ranged from $1.9 \%$ to $8.5 \%$, and was most frequent in recipients with DGF and dialysis $>2$ early periods. This 
Citation: Buchanan PM, Schnitzler MA, Axelrod D, Salvalaggio PR, Lentine KL (2011) The Clinical and Financial Burden of Early Dialysis After Deceased Donor Kidney Transplantation. J Nephrol Therapeutic S4:001. doi:10.4172/2161-0959.S4-001

Page 6 of 12

\begin{tabular}{|c|c|c|c|c|}
\hline Variable & Transplant hospitalization $^{\dagger}$ & $\begin{array}{l}\text { One year post } \\
\text { transplant }^{\dagger}\end{array}$ & $\begin{array}{l}\text { Two years post } \\
\text { transplant }^{\dagger}\end{array}$ & Three years post transplant $^{\dagger}$ \\
\hline Base Cost (Intercept) & $33173(31410 \text { to } 34936)^{*}$ & 57337 (52327 to 62346$)^{*}$ & 66255 (59137 to 73373$)$ * & $76000(66675$ to 85326$)$ * \\
\hline $\begin{array}{l}\text { DGF with early dialysis in first week } \\
\text { only }\end{array}$ & $2727(2323$ to 3131$)$ * & $6476(5299$ to 7652$)$ * & $7246(5537$ to 8954$) *$ & $8742(6456$ to 11029$) *$ \\
\hline $\begin{array}{l}\text { DGF and early dialysis in } 1 \\
\text { additional periods }^{\ddagger}\end{array}$ & 1219 (442 to 1997$)$ * & $17070(14794$ to 19346$)$ * & 18036 (14777 to 21295$)$ * & 21481 (17107 to 25855$)$ * \\
\hline $\begin{array}{l}\text { DGF and early dialysis in }>1 \\
\text { additional periods }^{\ddagger}\end{array}$ & 2461 (1379 to 3544$)$ * & 27606 (24497 to 30716$)$ * & 33675 (29221 to 38129$)$ * & 39855 (33856 to 45855$)$ * \\
\hline No DGF but some early dialysis ${ }^{\ddagger}$ & 1762 (868 to 2657$)$ * & 20013 (17448 to 22578$)$ * & 21984 (18408 to 25560$)$ * & 24846 (20265 to 29426$)^{*}$ \\
\hline No DGF and no early dialysis & Reference & Reference & Reference & Reference \\
\hline \multicolumn{5}{|l|}{ Recipient characteristics } \\
\hline Female & $-226(-599$ to 146$)$ & $-93(-1168$ to 983$)$ & 1207 (-334 to 2748$)$ & $3086(1053$ to 5120$)$ * \\
\hline \multicolumn{5}{|l|}{ Race } \\
\hline African American & $1318(879$ to 1757$)$ * & 1969 (690 to 3249$)$ * & 4532 (2691 to 6374$)$ * & $7543(5112 \text { to } 9974)^{*}$ \\
\hline White & Reference & Reference & Reference & Reference \\
\hline Other & 391 (-354 to 1136$)$ & $-5426(-7624 \text { to }-3228)^{*}$ & $-9224(-12397$ to -6052$) *$ & $-13901(-18094$ to -9708$) *$ \\
\hline \multicolumn{5}{|l|}{ Age (years) } \\
\hline $18-30$ & Reference & Reference & Reference & Reference \\
\hline $31-44$ & $-37(-722$ to 648$)$ & $192(-1764$ to 2148$)$ & 636 (-2134 to 3405$)$ & $329(-3254$ to 3911$)$ \\
\hline $45-59$ & $-597(-1273$ to 79$)$ & 976 (-960 to 2911$)$ & $1449(-1298$ to 4197$)$ & 620 (-2943 to 4182$)$ \\
\hline$\geq 60$ & $-291(-1010$ to 428$)$ & 3932 (1869 to 5996$)$ * & 4916 (1974 to 7859$) *$ & 3835 (-4 to 7675$)$ \\
\hline \multicolumn{5}{|l|}{ BMI category $\left(\mathrm{kg} / \mathrm{m}^{2}\right)$} \\
\hline$<10$ or Missing & $-289(-769$ to 191$)$ & $13(-1358$ to 1385$)$ & $474(-1462$ to 2411$)$ & $1325(-1176$ to 3825$)$ \\
\hline$\geq 10$ to $<25$ & Reference & Reference & Reference & Reference \\
\hline$\geq 25$ to $<30$ & $-951(-1421$ to -481$) *$ & $-2122(-3485$ to -759$){ }^{*}$ & $-1401(-3370$ to 568$)$ & $-2438(-5071$ to 196$)$ \\
\hline$\geq 30$ & $-1037(-1558$ to -516$)$ * & $266(-1257$ to 1790$)$ & $1050(-1167$ to 3267$)$ & $2272(-720$ to 5264$)$ \\
\hline \multicolumn{5}{|l|}{ Primary cause of ESRD } \\
\hline Diabetes mellitus & $2535(1910$ to 3160$)$ * & 13085 (11248 to 14923$)^{*}$ & 22012 (19388 to 24636$)$ * & 28111 (24658 to 31563$)$ * \\
\hline Hypertension & $1343(706$ to 1980$)$ * & $390(-1512$ to 2291$)$ & $1685(-1042$ to 4412$)$ & $1715(-1885$ to 5315$)$ \\
\hline Glomerulonephritis & $-480(-1125$ to 164$)$ & $-4148(-6054 \text { to }-2241)^{*}$ & $-5515(-8233$ to -2798$) *$ & $-7745(-11317 \text { to }-4173)^{*}$ \\
\hline Polycystic kidney disease & $126(-704$ to 956$)$ & $-3593(-6024 \text { to }-1161)^{*}$ & $-5395(-8883$ to -1908$)$ * & $-9005(-13620$ to -4389$)$ * \\
\hline Other & Reference & Reference & Reference & Reference \\
\hline Unknown & $1385(672$ to 2098$)$ * & 577 (-1525 to 2680$)$ & $1267(-1752$ to 4286$)$ & $846(-3120$ to 4812$)$ \\
\hline Hispanic & 507 (-72 to 1086$)$ & 3361 (1745 to 4977$)^{*}$ & 5217 (2909 to 7525$)^{*}$ & 6181 (3123 to 9239$)$ * \\
\hline Peripheral vascular disease & 233 (-668 to 1133$)$ & 6601 (4026 to 9176$)$ * & $11829(8152$ to 15505$)$ * & 14462 (9646 to 19278$)^{*}$ \\
\hline \multicolumn{5}{|l|}{ Pre-Transplant Dialysis } \\
\hline None (pre-emptive) & 1359 (436 to 2283$)$ * & $6174(3503$ to 8845$) *$ & $6680(2848$ to 10511$) *$ & 7769 (2669 to 12869$){ }^{*}$ \\
\hline $0-12$ months & Reference & Reference & Reference & Reference \\
\hline 13-24 months & $-1354(-2111$ to -596$){ }^{*}$ & $-2315(-4464$ to -167$)$ * & $-2626(-5650$ to 398$)$ & $-2150(-6038$ to 1737$)$ \\
\hline $25-60$ months & $-667(-1337$ to 3$)$ & $-858(-2760$ to 1045$)$ & $-1989(-4680$ to 702$)$ & $-3123(-6593$ to 348$)$ \\
\hline$>60$ months & $398(-352$ to 1147$)$ & $3270(1122 \text { to } 5417)^{*}$ & 3855 (789 to 6921$)$ * & $4895(885$ to 8904$) *$ \\
\hline \multicolumn{5}{|l|}{ Donor Characteristics } \\
\hline Female & $-392(-767$ to -18$)$ * & $-402(-1487$ to 683$)$ & $-229(-1787$ to 1329$)$ & $-28(-2087$ to 2031$)$ \\
\hline \multicolumn{5}{|l|}{ Race } \\
\hline African American & $698(143$ to 1253$)$ * & 2977 (1368 to 4585$)^{*}$ & $4979(2661$ to 7298$) *$ & $8448(5370$ to 11527$)$ * \\
\hline White & Reference & Reference & Reference & Reference \\
\hline Other & 857 (-77 to 1791$)$ & $-1(-2880$ to 2879$)$ & $303(-3872$ to 4477$)$ & 5889 (386 to 11393$)$ * \\
\hline \multicolumn{5}{|l|}{ Age (years) } \\
\hline$<18$ & 125 (-436 to 686$)$ & $561(-1051$ to 2172$)$ & $742(-1549$ to 3032$)$ & $1729(-1267$ to 4725$)$ \\
\hline $18-30$ & Reference & Reference & Reference & Reference \\
\hline $31-44$ & 725 (215 to 1236$)^{*}$ & 1889 (415 to 3363$)$ * & 1495 (-623 to 3612$)$ & $2639(-157$ to 5434$)$ \\
\hline $45-59$ & $998(458$ to 1538$)$ * & $3703(2135$ to 5271$) *$ & $5346(3076$ to 7616$) *$ & 7526 (4483 to 10569$)^{*}$ \\
\hline$\geq 60$ & $2127(1130$ to 3124$)$ * & $9117(6215$ to 12019$)$ * & $13809(9622$ to 17997$)$ * & 16626 (11016 to 22236$)^{*}$ \\
\hline \multicolumn{5}{|l|}{ BMI category $\left(\mathrm{kg} / \mathrm{m}^{2}\right)$} \\
\hline$<10$ or Missing & $499(-484$ to 1481$)$ & $-82(-2805$ to 2642$)$ & $301(-3401$ to 4004$)$ & $-1320(-5896$ to 3256$)$ \\
\hline$\geq 10$ to $<25$ & Reference & Reference & Reference & Reference \\
\hline$\geq 25$ to $<30$ & $-22(-446$ to 402$)$ & $-543(-1773$ to 686$)$ & $-797(-2569$ to 974$)$ & $-337(-2684$ to 2009$)$ \\
\hline$\geq 30$ & $148(-365$ to 661$)$ & $-192(-1686$ to 1302$)$ & $-1636(-3797$ to 525$)$ & $-2869(-5766$ to 27$)$ \\
\hline Death due to stroke & 361 (-73 to 795$)$ & $2443(1184$ to 3702$) *$ & 3881 (2064 to 5697$)$ * & $5822(3401$ to 8244$) *$ \\
\hline Terminal Creatinine $\geq 1.5 \mathrm{mg} / \mathrm{dl}$ & 967 (458 to 1477$)^{*}$ & 586 (-891 to 2063$)$ & $1036(-1089$ to 3161$)$ & $1796(-1008$ to 4600$)$ \\
\hline Hypertension history & 609 (79 to 1139$)$ * & $2759(1218$ to 4300$)$ * & $4005(1774$ to 6236$)$ * & $5767(2803$ to 8732$)$ * \\
\hline
\end{tabular}


Citation: Buchanan PM, Schnitzler MA, Axelrod D, Salvalaggio PR, Lentine KL (2011) The Clinical and Financial Burden of Early Dialysis After Deceased Donor Kidney Transplantation. J Nephrol Therapeutic S4:001. doi:10.4172/2161-0959.S4-001

Page 7 of 12

\begin{tabular}{|c|c|c|c|c|}
\hline Diabetes & $-123(-1050$ to 804$)$ & $376(-2326$ to 3079$)$ & 1825 (-2180 to 5831$)$ & $4006(-1447$ to 9460$)$ \\
\hline \multicolumn{5}{|l|}{ Transplant Factors } \\
\hline \multicolumn{5}{|l|}{ Donor Type } \\
\hline SCD & Reference & Reference & Reference & Reference \\
\hline ECD & 750 (-98 to 1598$)$ & 2069 (-401 to 4538$)$ & $3147(-418$ to 6711$)$ & $4494(-247$ to 9235$)$ \\
\hline DCD & $1969(831$ to 3107$)$ * & 4453 (947 to 7959$)$ * & $5079(-328$ to 10486$)$ & $4293(-3404$ to 11989$)$ \\
\hline \multicolumn{5}{|c|}{ Peak Panel Reactive Antibody (\%) } \\
\hline $0-10$ & 776 (197 to 1355$)$ * & 2547 (889 to 4205$)^{*}$ & $3842(1494$ to 6190$)$ * & $4924(1875$ to 7972$) *$ \\
\hline $11-30$ & Reference & Reference & Reference & Reference \\
\hline$>30$ & $2026(1487$ to 2566$)$ * & $6482(4927$ to 8037$) *$ & 10917 (8684 to 13149$){ }^{*}$ & $12567(9614 \text { to } 15520)^{*}$ \\
\hline Unknown & $2950(2054$ to 3847$) *$ & $7985(4395$ to 11576$))^{*}$ & $6113(750$ to 11476$) *$ & $4231(-2866$ to 11328$)$ \\
\hline \multicolumn{5}{|l|}{ HLA Mismatches } \\
\hline 0 & Reference & Reference & Reference & Reference \\
\hline 1 & $404(-508$ to 1316$)$ & $452(-2161$ to 3065$)$ & $-196(-3910$ to 3517$)$ & $2010(-2888$ to 6908$)$ \\
\hline 2 & $-326(-1126$ to 474$)$ & $684(-1608$ to 2976$)$ & 1147 (-2123 to 4417$)$ & 1799 (-2517 to 6116$)$ \\
\hline 3 & $-387(-1097$ to 322$)$ & 1106 (-944 to 3155$)$ & 2319 (-620 to 5258$)$ & $2181(-1706$ to 6067$)$ \\
\hline 4 & 391 (-308 to 1089) & 2600 (573 to 4628$)$ * & 3901 (979 to 6824$)$ * & 4697 (819 to 8576$)$ * \\
\hline 5 & $976(243$ to 1709$)$ * & $5956(3822 \text { to } 8090)^{*}$ & $8719(5628 \text { to } 11810)^{*}$ & $10145(6035 \text { to } 14254)^{*}$ \\
\hline 6 & 1606 (711 to 2502$)$ * & $6829(4229$ to 9429$) *$ & $8405(4633$ to 12178$)$ * & 10601 (5541 to 15660$)$ * \\
\hline Unknown & $2502(1163$ to 3842$) *$ & $7659(3831$ to 11487$)$ * & $13312(7932$ to 18691$)$ * & $16293(9370$ to 23217$)$ * \\
\hline \multicolumn{5}{|l|}{ CMV sero-pairing } \\
\hline Donor - / Recipient - & Reference & Reference & Reference & Reference \\
\hline Donor - / Recipient + & $-325(-961$ to 311$)$ & $-172(-2005$ to 1662$)$ & $-86(-2706$ to 2534$)$ & 2471 (-986 to 5928$)$ \\
\hline Donor + / Recipient - & 43 (-621 to 706$)$ & 6119 (4209 to 8029$)$ * & $8062(5332$ to 10792$) *$ & 10371 (6784 to 13959$)$ * \\
\hline Donor + / Recipient + & $-98(-693$ to 497$)$ & $1658(-58$ to 3374$)$ & $3020(568$ to 5473$)$ * & 5880 (2653 to 9108$)$ * \\
\hline Unknown & $64(-722$ to 849$)$ & 2877 (609 to 5145$)$ * & $5162(1941$ to 8383$)$ * & $9235(5019$ to 13450$)$ * \\
\hline \multicolumn{5}{|l|}{ Cold time (hours) } \\
\hline $0-14$ & Reference & Reference & Reference & Reference \\
\hline $15-19$ & $-325(-817$ to 167$)$ & $-1125(-2553$ to 303$)$ & $-1584(-3637$ to 469$)$ & $-794(-3513$ to 1924$)$ \\
\hline $20-25$ & $890(386$ to 1394$)$ * & $648(-810$ to 2106$)$ & 704 (-1389 to 2797$)$ & $617(-2143$ to 3377$)$ \\
\hline $26+$ & 4037 (3501 to 4573$)$ * & 5325 (3784 to 6865$)^{*}$ & $5649(3455$ to 7844$) *$ & $4429(1550$ to 7308$)$ * \\
\hline Unknown & $2978(2319$ to 3637$)$ * & 5036 (3103 to 6970$)^{*}$ & 4750 (1896 to 7605$)^{*}$ & $6270(2359 \text { to } 10181)^{*}$ \\
\hline \multicolumn{5}{|l|}{ Year } \\
\hline 1995 & Reference & Reference & Reference & Reference \\
\hline 1996 & $-1458(-2262 \text { to }-654)^{*}$ & $-2277(-4502$ to -53$)$ * & $-1673(-4685$ to 1338$)$ & $-1819(-5519$ to 1882$)$ \\
\hline 1997 & $-4418(-5192 \text { to }-3643)^{*}$ & $-6521(-8664$ to -4379$){ }^{*}$ & $-8239(-11141$ to -5336$)$ * & $-9645(-13213$ to -6077$)$ * \\
\hline 1998 & $-5952(-6736 \text { to }-5168)^{*}$ & $-11433(-13602$ to -9264$) *$ & $-12815(-15755$ to -9875$) *$ & $-13715(-17332$ to -10098$)$ * \\
\hline 1999 & $-7277(-8068 \text { to }-6485)^{*}$ & $-13947(-16138$ to -11757$)$ * & $-14618(-17588$ to -11647$)$ * & $-15831(-19488$ to -12173$)$ * \\
\hline 2000 & $-8297(-9093 \text { to }-7500)^{*}$ & $-11218(-13426$ to -9010$) *$ & $-10232(-13231$ to -7233$)$ * & $-10798(-14500$ to -7096$) *$ \\
\hline 2001 & $-9399(-10188$ to -8609$)$ * & $-13744(-15932$ to -11555$)$ * & $-14396(-17371$ to -11421$) *$ & $-15758(-19434$ to -12081$)$ * \\
\hline 2002 & $-11555(-12348$ to -10761$) *$ & $-18870(-21070$ to -16670$)$ * & $-19225(-22216$ to -16233$) *$ & - \\
\hline 2003 & $-13837(-14632$ to -13043$) *$ & $-23061(-25267$ to -20854$)$ * & 12991 (3764 to 22219$)$ * & - \\
\hline 2004 & $-15699(-16600$ to -14798$)$ * & 15414 (3619 to 27208$)$ * & $-7226(-23593$ to 9140$)$ & - \\
\hline
\end{tabular}

Costs adjusted to 2004 as the base year

${ }^{\dagger}$ Coefficient Estimates $(95 \% \mathrm{Cl})$.

${ }^{*}$ P-value $<0.05$.

¥ Periods of early dialysis were first week, the second week, weeks 3 or 4 , the second month and the third month post-transplant

Table 3: Multivariate regression estimates of adjusted cost drivers at transplant hospitalization and one, two, and three years in Medicare-insured transplant recipients from 1995-2004 (in US dollars).

group continued to have the highest rejection prevalence at 2 and 3 years post-transplant ( $12.5 \%$ and $14.5 \%$, respectively) while those with no early dialysis utilization consistently had the lowest rejection $(1.9 \%$, $4.0 \%$, and $5.1 \%$ at one, two and three years). The intensity of dialysis was correlated with length of hospital stay, serum creatinine, and eGFR at all time periods. Patients without dialysis requirements had the shortest length of stay, lowest serum creatinine, and highest eGFR at all follow-up points.

Graft survival varied significantly based on post-transplant dialysis utilization $(\mathrm{p}<0.0001)$, being best in those with no early dialysis utilization and worst in those with DGF and dialysis in $>2$ subsequent periods (Figure 1A). Patterns were similar for patient survival, such that patients with DGF and dialysis in $>2$ early periods had approximately $10 \%$ lower survival by one year post-transplant compared to those with no early dialysis utilization (Figure 1B). After adjusting for recipient, donor, and transplant characteristics, posttransplant dialysis utilization was associated with lower graft and patient survival compared to no early dialysis utilization (Table 5). Patients who experienced DGF and received dialysis in $>2$ early periods were more than twice as likely to lose their grafts within 3 years as those 


\begin{tabular}{|c|c|c|c|c|c|c|c|}
\hline & $\mathrm{N}$ at Risk & $\begin{array}{l}\text { DGF and early } \\
\text { dialysis in } \\
1 \text { additional } \\
\text { period, } \pm n(\%) \text { ) }\end{array}$ & $\begin{array}{l}\text { DGF and early } \\
\text { dialysis in } \\
>1 \text { additional } \\
\text { period, } \neq n(\%)\end{array}$ & $\begin{array}{l}\text { No DGF but } \\
\text { some early } \\
\text { dialysis, }{ }^{ \pm}(\%)^{*}\end{array}$ & $\begin{array}{l}\text { No DGF and no } \\
\text { dialysis, }{ }^{\ddagger} \mathrm{n}(\%)^{*}\end{array}$ & p-value ${ }^{\dagger}$ & p-value* \\
\hline & & n (\%) & n (\%) & n (\%) & n (\%) & n (\%) & \\
\hline \multicolumn{8}{|l|}{ Rejection ${ }^{\dagger \dagger}$} \\
\hline 1 year post transplant & 37,533 & $314(2.6)$ & $99(4.6)$ & $88(8.5)$ & $71(4.7)$ & $389(1.9)$ & $<0.0001$ \\
\hline 2 year post transplant & 37,533 & $574(4.7)$ & $173(8.1)$ & $130(12.5)$ & $109(7.2)$ & $817(4.0)$ & $<0.0001$ \\
\hline \multirow[t]{2}{*}{3 year post transplant } & 37,533 & 709 (5.9) & $198(9.3)$ & $151(14.5)$ & $132(8.7)$ & $1060(5.1)$ & $<0.0001$ \\
\hline & & mean (std) & mean (std) & mean (std) & mean $(\mathrm{std})$ & mean $(\mathrm{std})$ & \\
\hline Length of stay (days) & 22,269 & $11.6(31.7)$ & $13.1(55.4)$ & $17.6(83.7)$ & $11.3(31.9)$ & $9.4(45.9)$ & $<0.0001$ \\
\hline \multicolumn{8}{|l|}{ Serum Creatinine (mg/dl) } \\
\hline Discharge & 36,867 & $4.2(2.9)$ & $6.7(3.5)$ & $7.3(3.4)$ & $2.9(2.4)$ & $2.2(1.6)$ & $<0.0001$ \\
\hline 6 months post transplant & 35,514 & $1.7(0.8)$ & $1.9(1.0)$ & $2.1(1.1)$ & $1.7(0.8)$ & $1.5(0.7)$ & $<0.0001$ \\
\hline 1 year post transplant & 33,957 & $1.7(0.8)$ & $1.9(1.0)$ & $2.1(1.0)$ & $1.8(1.1)$ & $1.5(0.7)$ & $<0.0001$ \\
\hline \multicolumn{8}{|l|}{ eGFR $\left(\mathrm{ml} / \mathrm{min} / 1.73 \mathrm{~m}^{2}\right)$} \\
\hline Discharge & 36,867 & $27.3(21.0)$ & $15.4(16.2)$ & $13.7(15.9)$ & $40.6(43.6)$ & $45.9(35.4)$ & $<0.0001$ \\
\hline $\begin{array}{l}6 \text { month post } \\
\text { transplant }\end{array}$ & 35,514 & $52.7(22.9)$ & $48.1(20.5)$ & $44.7(21.6)$ & $52.3(32.9)$ & $57.3(22.1)$ & $<0.0001$ \\
\hline 1 year post transplant & 33,957 & $52.5(21.1)$ & $47.9(20.1)$ & $44.4(20.5)$ & $51.9(21.0)$ & $56.7(22.7)$ & $<0.0001$ \\
\hline
\end{tabular}

* $P$ value for the difference in trait distribution according to early post-transplant dialysis utilization was computed by the Chi-square test for categorical variables and ANOVA F-tests for continuous variables.

tPeriods of early dialysis were first week, the second week, weeks 3 or 4 , the second month and the third month post-transplant

${ }^{\dagger+}$ Rejection is defined as any OPTN reported rejection with in the indicated period

¥ Missing data is excluded from the analysis.

Table 4: Graft outcomes according to early post-transplant dialysis utilization.

who did not receive early dialysis $(\mathrm{p}<0.0001)$. Dialysis in the first week only increased the risk of graft failure and death by $24 \%(\mathrm{p}<0.0001$ for both comparisons). After adjustment for dialysis utilization and other factors, recipients of ECD transplants were $10 \%$ more likely to experience graft failure and $20 \%$ more likely to experience death than recipients of SCD transplants $(\mathrm{p}=0.04$ and $\mathrm{p}=0.003$ respectively). Year of transplant was not associated with patient or graft survival after accounting for other factors

\section{Discussion}

Our study examined the cost of care for the transplant hospitalization and at one, two, and three years post transplant for adult Medicare recipients of deceased donor kidneys in 1995 to 2004 in the United States. We assessed the implications of dialysis utilization early after transplant. A major observation was that patients who receive early post-transplant dialysis are not a homogenous group with respect to costs of care and clinical outcomes. Patients experiencing DGF incurred an additional $\$ 1,200$ to $\$ 2,700$ in adjusted costs during the transplant hospitalization. By one year after transplant, there was a graded increase in the incremental cost of care according to the duration of early dialysis utilization, ranging from $\$ 6,500$ in those with dialysis confined to the first week to $\$ 27,600$ in those with DGF and dialysis in $>2$ additional early periods.

In addition to increased cost, dialysis utilization in the first 90 days post transplant is also a marker for poorer clinical outcomes including higher serum creatinine, lower eGFR and longer length of stay. Patients who require dialysis also have more common rejection in the 3 years post transplant, especially those with sustained early dialysis utilization. They also experience worse graft and patient survival. Our results are similar to those of Humar et al. [21,22] who found that both DGF and slow graft function (SGF) are associated with higher acute rejection rates and worse graft survival [21].

Our results show that not only is dialysis in the first week posttransplant a marker for worse clinical and cost outcomes but that early dialysis in the first 8 to 90 days is associated with similarly adverse, if not worse, outcomes. This observation supports a need for a broader definition of DGF that includes graft dysfunction which occurs after the first weekpost transplant. Some studies have explored the concept of SGF in terms of serum creatinine levels in patients who do not require dialysis, but thresholds of elevated creatinine varied across studies [2123]. Further, most of these definitions consider function only within the first week post-transplant. The need for dialysis beyond the first week, yet still early after transplant needs to be considered. Definitions of DGF and SGF severity that reflect the amount and frequency of early post-transplant dialysis should be formalized. Prospective studies considering eGFR levels and the amount and the amount and frequency of dialysis requirements in relation to outcomes are warranted.

In recent years UNOS has been encouraging the utilization of ECD and DCD kidneys in order to increase the donor supply [24]. While these allografts may remove patients from the wait-list faster than waiting for an SCD kidney, the organs come with additional risk. This includes an increased risk of DGF and graft failure compared to SCD kidneys [23,25]. These outcomes often lead to more frequent and longer hospitalizations which increase the cost of care [16,25]. Merion et al. [26] suggested that given these increased risks, the use of ECD kidneys should be targeted at specific recipient groups including older patients, those with diabetes, and patients who live in areas with very long waiting times.

A number of studies have demonstrated strong associations of 
Citation: Buchanan PM, Schnitzler MA, Axelrod D, Salvalaggio PR, Lentine KL (2011) The Clinical and Financial Burden of Early Dialysis After Deceased Donor Kidney Transplantation. J Nephrol Therapeutic S4:001. doi:10.4172/2161-0959.S4-001

Page 9 of 12

\begin{tabular}{|c|c|c|c|c|}
\hline \multirow[b]{2}{*}{ Variable } & \multicolumn{2}{|c|}{ Patient Death } & \multicolumn{2}{|l|}{ Graft Failure } \\
\hline & Odds Ratio & $95 \% \mathrm{Cl}$ & Odds Ratio & $95 \% \mathrm{Cl}$ \\
\hline $\begin{array}{l}\text { DGF with early dialysis in first week } \\
\text { only }\end{array}$ & 1.24 & $(1.17 \text { to } 1.32)^{*}$ & 1.24 & $(1.18 \text { to } 1.3)^{*}$ \\
\hline $\begin{array}{l}\text { DGF and early dialysis in } 1 \\
\text { additional periods }^{\ddagger}\end{array}$ & 1.60 & $(1.45 \text { to } 1.78)^{*}$ & 1.66 & $(1.53 \text { to } 1.8)^{*}$ \\
\hline $\begin{array}{l}\text { DGF and early dialysis in }>1 \\
\text { additional periods }^{\ddagger}\end{array}$ & 2.08 & $(1.83 \text { to } 2.36)^{*}$ & 2.23 & $(2.02 \text { to } 2.47)^{*}$ \\
\hline No DGF but some early dialysis ${ }^{\ddagger}$ & 1.61 & $(1.44 \text { to } 1.8)^{*}$ & 1.54 & $(1.41$ to 1.69$)$ * \\
\hline No DGF and no early dialysis & \multicolumn{2}{|l|}{ Reference } & \multicolumn{2}{|l|}{ Reference } \\
\hline \multicolumn{5}{|l|}{ Recipient characteristics } \\
\hline Female & 0.92 & $(0.87 \text { to } 0.97)^{*}$ & 0.91 & $(0.87$ to 0.95$)$ * \\
\hline \multicolumn{5}{|l|}{ Race } \\
\hline African American & 0.94 & $(0.88 \text { to } 1.01)^{*}$ & 1.27 & $(1.21$ to 1.33$)$ * \\
\hline White & Reference & & Reference & \\
\hline Other & 0.70 & $(0.61 \text { to } 0.8)^{*}$ & 0.79 & $(0.71$ to 0.88$)$ * \\
\hline \multicolumn{5}{|l|}{ Age (years) } \\
\hline $18-30$ & Reference & & Reference & \\
\hline $31-44$ & 1.41 & $(1.21 \text { to } 1.63)^{*}$ & 0.86 & $(0.8 \text { to } 0.94)^{*}$ \\
\hline $45-59$ & 2.17 & $(1.88 \text { to } 2.5)^{*}$ & 0.86 & $(0.79$ to 0.93$)$ * \\
\hline$\geq 60$ & 3.38 & $(2.93 \text { to } 3.89)^{*}$ & 1.06 & (0.98 to 1.16$)$ \\
\hline \multicolumn{5}{|l|}{ BMI category $\left(\mathrm{kg} / \mathrm{m}^{2}\right)$} \\
\hline$<10$ or Missing & 1.01 & (0.95 to 1.08$)$ & 1.04 & (0.99 to 1.1$)$ \\
\hline$\geq 10$ to $<25$ & Reference & & Reference & \\
\hline$\geq 25$ to $<30$ & 0.91 & $(0.85 \text { to } 0.98)^{*}$ & 0.95 & (0.9 to 1.01$)$ \\
\hline$\geq 30$ & 1.02 & (0.94 to 1.11$)$ & 1.09 & $(1.02$ to 1.16$)$ * \\
\hline \multicolumn{5}{|l|}{ Primary cause of ESRD } \\
\hline Diabetes mellitus & 1.55 & $(1.41 \text { to } 1.7)^{*}$ & 1.19 & $(1.1 \text { to } 1.28)^{*}$ \\
\hline Hypertension & 1.05 & (0.95 to 1.16$)$ & 1.07 & (0.99 to 1.15$)$ \\
\hline Glomerulonephritis & 0.81 & $(0.73 \text { to } 0.9)^{*}$ & 0.90 & $(0.83$ to 0.98$)$ * \\
\hline Polycystic kidney disease & 0.66 & $(0.58 \text { to } 0.76)^{*}$ & 0.70 & $(0.63$ to 0.78$)$ * \\
\hline Other & Reference & & Reference & \\
\hline Unknown & 1.00 & (0.89 to 1.12$)$ & 1.02 & (0.93 to 1.11$)$ \\
\hline Hispanic & 1.49 & $(1.36 \text { to } 1.63)^{*}$ & 1.24 & $(1.16$ to 1.33$)$ * \\
\hline Peripheral vascular disease & 1.32 & $(1.19 \text { to } 1.46)^{*}$ & 1.24 & $(1.13$ to 1.36$)$ * \\
\hline \multicolumn{5}{|l|}{ Pre-Transplant Dialysis } \\
\hline None (pre-emptive) & 0.96 & $(0.84$ to 1.11$)$ & 0.92 & (0.83 to 1.03$)$ \\
\hline $0-12$ months & Reference & & Reference & \\
\hline 13-24 months & 1.02 & (0.92 to 1.14$)$ & 1.00 & (0.92 to 1.08$)$ \\
\hline $25-60$ months & 1.00 & (0.92 to 1.1$)$ & 0.94 & (0.87 to 1.01$)$ \\
\hline$>60$ months & 1.15 & $(1.03 \text { to } 1.28)^{*}$ & 1.00 & (0.92 to 1.09$)$ \\
\hline \multicolumn{5}{|l|}{ Donor Characteristics } \\
\hline Female & 1.03 & (0.98 to 1.09$)$ & 1.08 & $(1.04$ to 1.13$)$ * \\
\hline \multicolumn{5}{|l|}{ Race } \\
\hline African American & 1.08 & (0.99 to 1.17$)$ & 1.18 & $(1.11$ to 1.26$)$ * \\
\hline White & Reference & & Reference & \\
\hline Other & 0.98 & (0.84 to 1.14$)$ & 1.00 & (0.89 to 1.13$)$ \\
\hline \multicolumn{5}{|l|}{ Age (years) } \\
\hline$<18$ & 1.03 & (0.94 to 1.12$)$ & 1.03 & (0.96 to 1.1$)$ \\
\hline $18-30$ & Reference & & Reference & \\
\hline $31-44$ & 1.05 & (0.97 to 1.13$)$ & 1.10 & $(1.03 \text { to } 1.17)^{*}$ \\
\hline $45-59$ & 1.17 & $(1.07 \text { to } 1.26)^{*}$ & 1.25 & $(1.17$ to 1.34$)$ * \\
\hline$\geq 60$ & 1.19 & $(1.04 \text { to } 1.36)^{*}$ & 1.44 & $(1.29 \text { to } 1.6)^{*}$ \\
\hline \multicolumn{5}{|l|}{ BMI category $\left(\mathrm{kg} / \mathrm{m}^{2}\right)$} \\
\hline$<10$ or Missing & 0.97 & $(0.86$ to 1.1$)$ & 1.01 & (0.91 to 1.11$)$ \\
\hline$\geq 10$ to $<25$ & Reference & & Reference & \\
\hline$\geq 25$ to $<30$ & 0.94 & (0.88 to 1$)$ & 0.95 & (0.9 to 1$)$ \\
\hline$\geq 30$ & 1.01 & (0.94 to 1.09$)$ & 0.95 & (0.9 to 1.01$)$ \\
\hline Death due to stroke & 1.09 & $(1.02 \text { to } 1.16)^{*}$ & 1.11 & $(1.05 \text { to } 1.17)^{*}$ \\
\hline Terminal Creatinine $\geq 1.5 \mathrm{mg} / \mathrm{dl}$ & 0.94 & (0.87 to 1.01$)$ & 1.01 & (0.96 to 1.08$)$ \\
\hline Hypertension history & 1.02 & (0.95 to 1.1$)$ & 1.06 & $(1$ to 1.13$)$ * \\
\hline Diabetes & 1.14 & $(1 \text { to } 1.29)^{*}$ & 1.16 & $(1.04$ to 1.28$)$ * \\
\hline
\end{tabular}


Citation: Buchanan PM, Schnitzler MA, Axelrod D, Salvalaggio PR, Lentine KL (2011) The Clinical and Financial Burden of Early Dialysis After Deceased Donor Kidney Transplantation. J Nephrol Therapeutic S4:001. doi:10.4172/2161-0959.S4-001

Page 10 of 12

\begin{tabular}{|c|c|c|c|c|}
\hline Transplant Factors & & & & \\
\hline \multicolumn{5}{|l|}{ Donor Type } \\
\hline SCD & Reference & & Reference & \\
\hline ECD & 1.19 & $(1.06 \text { to } 1.33)^{*}$ & 1.10 & $(1.01 \text { to } 1.2)^{*}$ \\
\hline DCD & 1.07 & (0.88 to 1.3$)$ & 1.02 & (0.87 to 1.19$)$ \\
\hline \multicolumn{5}{|c|}{ Peak Panel Reactive Antibody (\%) } \\
\hline $0-10$ & Reference & & Reference & \\
\hline $11-30$ & 1.02 & $(0.94$ to 1.1$)$ & 1.07 & (1 to 1.14$)$ \\
\hline$>30$ & 1.19 & $(1.1 \text { to } 1.28)^{*}$ & 1.22 & $(1.15 \text { to } 1.3)^{*}$ \\
\hline Unknown & 1.19 & $(1.01 \text { to } 1.42)^{*}$ & 1.10 & $(0.95$ to 1.26$)$ \\
\hline \multicolumn{5}{|l|}{ HLA Mismatches } \\
\hline 0 & Reference & & Reference & \\
\hline 1 & 1.09 & (0.96 to 1.25$)$ & 1.08 & (0.97 to 1.22$)$ \\
\hline 2 & 1.10 & (0.97 to 1.23$)$ & 1.18 & $(1.07 \text { to } 1.3)^{*}$ \\
\hline 3 & 1.16 & $(1.04 \text { to } 1.29)^{*}$ & 1.22 & $(1.11$ to 1.33$)$ * \\
\hline 4 & 1.18 & $(1.06 \text { to } 1.32)^{*}$ & 1.30 & $(1.19 \text { to } 1.42)^{*}$ \\
\hline 5 & 1.21 & $(1.08 \text { to } 1.35)^{*}$ & 1.29 & $\left(1.17\right.$ to $\left.1.41^{*}\right)$ \\
\hline 6 & 1.22 & $(1.06 \text { to } 1.4)^{*}$ & 1.34 & $(1.2 \text { to } 1.5)^{*}$ \\
\hline Unknown & 1.20 & $(1 \text { to } 1.45)^{*}$ & 1.27 & $(1.09 \text { to } 1.47)^{*}$ \\
\hline \multicolumn{5}{|l|}{ CMV sero-pairing } \\
\hline Donor - / Recipient - & Reference & & Reference & \\
\hline Donor - / Recipient + & 1.15 & $(1.04 \text { to } 1.27)^{*}$ & 1.12 & $(1.03 \text { to } 1.21)^{*}$ \\
\hline Donor + / Recipient - & 1.27 & $(1.15 \text { to } 1.42)^{*}$ & 1.24 & $(1.14 \text { to } 1.35)^{*}$ \\
\hline Donor + / Recipient + & 1.23 & $(1.11 \text { to } 1.35)^{*}$ & 1.16 & $(1.08 \text { to } 1.25)^{*}$ \\
\hline Unknown & 1.21 & $(1.07 \text { to } 1.36)^{*}$ & 1.17 & $(1.06$ to 1.28$)$ * \\
\hline \multicolumn{5}{|l|}{ Cold time (hours) } \\
\hline $0-14$ & Reference & & Reference & \\
\hline $15-19$ & 0.99 & (0.92 to 1.07$)$ & 1.02 & (0.96 to 1.08$)$ \\
\hline $20-25$ & 1.07 & (1 to 1.16$)$ & 1.11 & $(1.05$ to 1.18$)$ * \\
\hline $26+$ & 1.05 & (0.97 to 1.13$)$ & 1.07 & $(1.01 \text { to } 1.14)^{*}$ \\
\hline Unknown & 1.01 & (0.9 to 1.13$)$ & 1.03 & (0.95 to 1.13$)$ \\
\hline \multicolumn{5}{|l|}{ Year } \\
\hline 1995 & Reference & & Reference & \\
\hline 1996 & 0.94 & (0.85 to 1.03$)$ & 0.94 & (0.87 to 1.02$)$ \\
\hline 1997 & 0.99 & (0.9 to 1.09$)$ & 0.95 & (0.88 to 1.02$)$ \\
\hline 1998 & 1.01 & (0.91 to 1.11$)$ & 0.95 & (0.88 to 1.02$)$ \\
\hline 1999 & 0.99 & (0.89 to 1.1$)$ & 0.92 & (0.85 to 1$)$ \\
\hline 2000 & 1.09 & (0.97 to 1.21$)$ & 1.02 & (0.94 to 1.11$)$ \\
\hline 2001 & 1.04 & (0.92 to 1.17$)$ & 0.92 & (0.84 to 1.01$)$ \\
\hline 2002 & 0.96 & (0.83 to 1.1$)$ & 0.96 & (0.86 to 1.06$)$ \\
\hline 2003 & 0.96 & (0.82 to 1.14$)$ & 0.90 & (0.79 to 1.03$)$ \\
\hline 2004 & 0.92 & (0.7 to 1.22$)$ & 0.90 & (0.73 to 1.12$)$ \\
\hline
\end{tabular}

* P-value $<0.05$

tPeriods of early dialysis were first week, the second week, weeks 3 or 4 , the second month and the third month post-transplant

Table 5: Adjusted associations of early post-transplant dialysis utilization with graft failure and patient death.

non-standard deceased-donor organs with increased need for early dialysis after transplant $[25,27,28]$. For example, one large registry study documented DGF in over $42 \%$ of DCD transplants in recent US practice [28]. Another large registry study found DGF occurred in $31 \%$ of ECD recipients, compared to $19 \%$ in non-ECD recipients [29]. Thus, use of these organs is expected to increase expenditures based on increased risk of early dialysis requirements. Further, we also detected associations of DCD kidneys with significant increase in cost even after adjusting for early post-transplant dialysis utilization. ECD kidneys were associated with a trend towards higher incremental costs after adjusting for early post-transplant dialysis utilization and other covariates. This can have a detrimental effect on the finances of a transplant center, as marginal organs are being used more often and kidney transplantation is reimbursed by Medicare at a fixed rate, regardless of the kidney quality or patient comorbidity [30-32].

Our results also support those of Englesbe et al. [6] who showed that ECD transplants and cases of DGF are associated with a decrease in their institution's profit margin as well as an increase in cost and decrease in Medicare reimbursement over time [6]. We not only found early post transplant dialysis utilization to be costly, but also found that Medicare is paying less per transplant per year. Total payments have been decreasing at a rate of over $\$ 1,500$ a year. Compared to 1995 Medicare reimbursed almost $\$ 16,000$ less per transplant in 2004 . These results suggest there will be an increasing burden on transplant centers which utilize organs associated with early post transplant dialysis requirements to expand the organ supply.

ECDs and DCDs kidneys have been shown to be associated with an increased risk of DGF, which in turn is associated with increased 


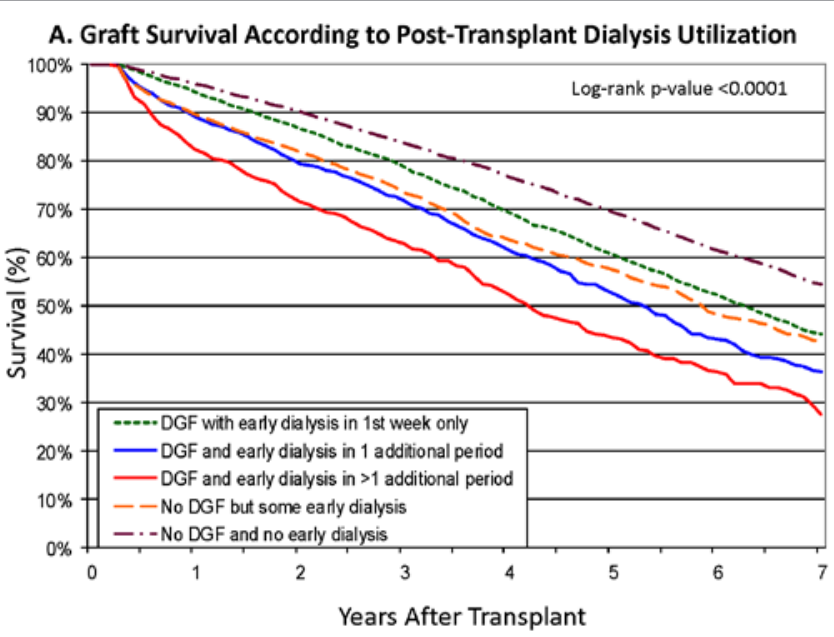

\section{B. Patient Survival According to Post-Transplant Dialysis Utilization}

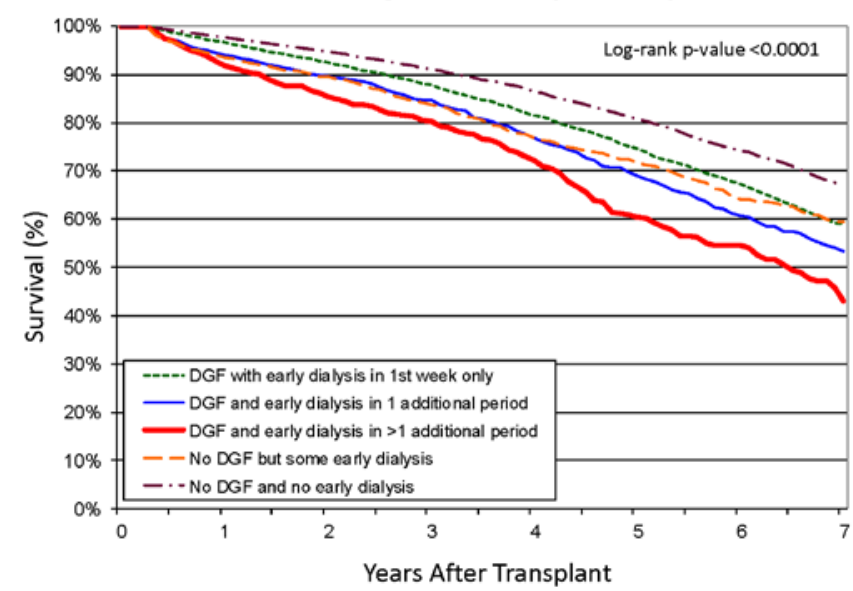

Figure 1: Graft and patient survival of Medicare-insured renal transplant recipients in the USRDS 1995-2004 according to early post-transplant dialysis utilization.

costs $[23,32]$. In order to minimize the economic impact of these organs and expand the organ supply we propose that the DRG for kidney transplantation should be different for each donor type. Kidneys associated with better outcomes and thus a lower cost (SCD kidneys) should have a DRG associated with a lower reimbursement by Medicare compared to DRGs for kidneys shown to be associated with poorer outcomes, such as ECD and some DCD kidneys. In the future, this reimbursement could be graded based on a donor profile index or another continuous scale.

Our study has several limitations. First, given a retrospective registry design we could not control for variables that were not collected in the USRDS database. Our multivariate models were adjusted for a number of factors associated with costs and clinical outcomes in other studies [27]. However, other clinical factors not recorded in the registry may drive costs. A prospective study is needed to determine if the cost associations we found are due to dialysis utilization and not the characteristics of the population. Secondly, our sample was restricted to patients with Medicare as the primary insurer and our findings may not generalize to beneficiaries of private insurance. We applied strict inclusion criteria to limit the possibility that study participants were using Medicare as a secondary insurer. Third, analyses of serum creatinine/eGFR after transplant may be affected by survivor bias in that patients who died or lost their graft and may have had worse renal function are not represented. Finally not all transplant centers submit separate charges to Medicare for dialysis that occurs in the first week post transplant as some bundle inpatient dialysis charges with the transplant hospitalization charge. Thus we were unable to determine how many sessions of dialysis and how frequently the sessions were occurring for the recipients who experienced DGF. Redefining how DGF is reported to the OPTN can allow for a more detailed study of DGF.

In summary, we found that Medicare is paying less each year for a transplant even as more marginal kidneys are being used to increase the donor supply. These marginal kidneys have an increase rate of DGF and dialysis initiated after the first post transplant week. DGF and additional early post-transplant early dialysis are costly at the time of transplant and result in higher longterm costs. In order to reduce the economic disincentive to use marginal kidneys, Medicare should consider reimbursement rates based on organ quality.

\section{Acknowledgments}

The data reported here have been supplied by the United States Rena Data System (USRDS). The interpretation and reporting of these data are the responsibility of the author(s) and in no way should be seen as an official policy or interpretation of the U.S. government. Drs. Schnitzler, Axelrod, Salvalaggio and Lentine received support from an American Recovery and Reinvestment Act grant from the National Institute of Diabetes Digestive and Kidney Diseases, RC11RC1DK086450.

\section{References}

1. Matas AJ, Schnitzler M (2004) Payment for living donor (vendor) kidneys: a cost-effectiveness analysis. American Journal of Transplantation 4: 216-221.

2. Ojo AO, Hanson JA, Meier-Kriesche H, Okechukwu CN, Wolfe RA, et al. (2001) Survival in recipients of marginal cadaveric donor kidneys compared with other recipients and wait-listed transplant candidates. Journal of the American Society of Nephrology 12: 589-597.

3. Wolfe RA, Ashby VB, Milford EL, Ojo AO, Ettenger RE, et al. (1999) Comparison of mortality in all patients on dialysis, patients on dialysis awaiting transplantation, and recipients of a first cadaveric transplant. The New England Journal of Medicine 341: 1725-1730.

4. Organ Procurement and Transplant Network (Access date February 23, 2011)

5. U.S. Renal Data System: USRDS (2008) Annual Data Report. Bethesda National Institutes of Health, National Institute of Diabetes and Digestive and Kidney Diseases. Altas of ESRD, Transplantation.

6. Englesbe MJ, Ads Y, Cohn JA, Sonnenday CJ, Lynch R, et al. (2008) The effects of donor and recipient practices on transplant center finances. American Journal of Transplantation 8: 586-592.

7. Doshi MD, Hunsicker LG (2007) Short- and long-term outcomes with the use of kidneys and livers donated after cardiac death. American Journal of Transplantation 7: 122-129.

8. Daly PJ, Power RE, Healy DA, Hickey DP, Fitzpatrick JM, et al. (2005) Delayed graft function: a dilemma in renal transplantation. BJU International 96: 498501

9. Boom H, Mallat MJ, De Fijter J, Zwinderman AH, Paul LC (2000) Delayed graft function influences renal function, but not survival. Kidney International 58 859-866.

10. Giral-Classe M, Hourmant M, Cantarovich D, Dantal J, Blancho G et al. (1998) Delayed graft function of more than six days strongly decreases long-term survival of transplanted kidneys. Kidney International 54: 972-978.

11. Almond PS, Troppmann C, Escobar F, Frey DJ, Matas AJ (1991) Economic impact of delayed graft function. Transplantation Proceedings 23: 1304.

12. Rosenthal JT, Danovitch GM, Wilkinson A, Ettenger RB (1991) The high cost of delayed graft function in cadaveric renal transplantation. Transplantation 51 : 1115-1118. 
Citation: Buchanan PM, Schnitzler MA, Axelrod D, Salvalaggio PR, Lentine KL (2011) The Clinical and Financial Burden of Early Dialysis After Deceased Donor Kidney Transplantation. J Nephrol Therapeutic S4:001. doi:10.4172/2161-0959.S4-001

13. Sanfilippo F, Vaughn WK, Spees EK, Lucas BA (1984) The detrimental effects of delayed graft function in cadaver donor renal transplantation. Transplantation 38: $643-648$

14. Schold JD, Kaplan B, Baliga RS, Meier-Kriesche HU (2005) The broad spectrum of quality in deceased donor kidneys. American Journal of Transplantation 5: 757-765

15. Wight J, Chilcott J, Holmes M, Brewer N (2003) The clinical and costeffectiveness of pulsatile machine perfusion versus cold storage of kidneys for transplantation retreived from heart-beating and non-heart-beating donors. Health Technology Assessment 7: 1-94.

16. Almond PS, Matas AJ, Canafax DM (1991) Fixed-rate reimbursement fails to cover costs for patients with delayed graft function. Pharmacotherapy 11: 126129 .

17. USRenal Data System (2006) Researchers guide to the USRDS database. In: National Institutes of Health NloDaDaKD, Bethesda, MD: Researcher guide to the USRDS database.

18. Whiting JF, Woodward RS, Zavala EY,Cohen DS, Martin JE, et al. (2000) Economic cost of expanded criteria donors in cadaveric renal transplantation: analysis of Medicare payments. Transplantation 70: 755-760

19. Bureau of Labor Statistics. Consumer Price Index, US Average Medical Care. (Access Date August 7, 2011).

20. Poggio ED, Wang X, Weinstein DM, Issa N, Dennis VW, et al. (2006) Assessing glomerular filtration rate by estimation equations in kidney transplant recipients. American Journal of Transplantation 6: 100-108

21. Humar A, Johnson E, Payne W, Wrenshall L, Sutherland DE, et al. (1997) Effect of initial slow graft function on renal allograft rejection and survival. Clinical Transplantation 11: 623-627.

22. Humar A, Ramcharan T, Kandaswamy R, Gillingham K, Payne WD, et al (2002) Risk factors for slow graft function after kidney transplants: a multivariate analysis. Clinical Transplantation 16: 425-429.
23. Yarlagadda S, Klein C, Jani A (2008) Long-term renal outcomes after delayed graft function. Advances in Chronic Kidney Disease 15: 248-256.

24. Caro F, Shirabe T, Guignard M, Weintraub A (2004) School redistricting embedding GIS tools with integer programming. Journal of the Operational Research Society 55: 836-849.

25. Saidi RF, Elias N, Kawai T, Hertl M, Farrell ML, et al. (2007) Outcome of kidney transplantation using expanded criteria donors and donation after cardiac death kidneys: realities and costs. American Journal of Transplantation 7: 2769-2774.

26. Merion RM, Ashby VB, Wolfe RA, Distant DA, Hulbert-Shearon et al (2005) Deceased-donor characteristics and the survival benefit of kidney transplantation. Journal of the American Medical Association 294: 2726-2733.

27. Irish WD, McCollum DA, Tesi RJ, Owen AB, Brennan DC, et al. (2003) Nomogram for predicting the likelihood of delayed graft function in adult cadaveric renal transplant recipients. Journal of the American Society of Nephrology 14: 2967-2974.

28. Rudich SM, Kaplan B, Magee JC, Arenas JD, Punch JD et al. (2002) Rena transplantations performed using non-heart-beating organ donors: going back to the future?. Transplantation 74: 1715-1720.

29. Johnston TD, Thacker LR, Jeon H, Lucas BA, Ranjan D (2004) Sensitivity of expanded-criteria donor kidneys to cold ischaemia time. Clinical Transplantation 18: 28-32.

30. Annual Report of the U.S (2007) Organ Procurement and Transplantation Network and the Scientific Registry of Transplant Recipients: Transplant Data 1997-2006. Health Resources and Services Administration HS.

31. Hirth R (2007) The organization and financing of kidney dialysis and transplan care in the United States of America. Int J Health Care Finance Econ 7: 301 318.

32. Whiting JF, Woodward RS, Zavala EY, Cohen DS, Martin JE, et al. (2000) Economic cost of expanded criteria donors in cadaveric renal transplantation: analysis of Medicare payments. Transplantation 70: 755-760.
This article was originally published in a special issue, Kidney

Transplantation handled by Editor(s). Dr. Gagangeet Sandhu, Columbia

University College of Physicians and Surgeons, USA; Dr. Krista Lentine, Saint

Louis University School of Medicine, USA 